\title{
Faktor-Faktor Yang Berhubungan Dengan Pemanfaatan Voluntary Counselling and Testing (VCT) Pada Ibu Hamil di Wilayah Kerja Puskesmas Karanganyar Kota Tasikmalaya
}

\author{
Dudi Ahmad $\mathbf{M}^{1}$, Sri Mulyanti ${ }^{2}$, Neni Nuraeni ${ }^{3}$
}

\begin{abstract}
Abstrak
Human Immunodeficiency Virus (HIV) merupakan suatu keadaan dimana seseorang tidak memiliki kekebalan tubuh. Penyakit tersebut dapat menular dari ibu hamil kepada anak yang dikandungnya, sebagai upaya untuk deteksi dini terhadap HIV maka perlu dilakukan VCT. Data Puskesmas Karanganyar pada tahun Cakupan layanan VCT pada ibu hamil tahun 2017 kurang dari 26,7\%. Penelitian ini bertujuan untuk mengetahui faktor-faktor yang berhubungan dengan dengan pemanfaatan VCT pada ibu hamil. Jenis penelitian ini kuantitatif dengan menggunakan metode deskriptif korelasi dan pendekatan cross sectional. Populasi adalah ibu hamil yang berjumlah 70 orang yang diperoleh denganteknik purposive sampling. Data diperoleh dengan kuesioner tertutup dan data dianalisis dengan menggunakan distribusi frekuensidan uji chi square. Hasil penelitian menunjukan Pengetahuan tentang pemeriksaan VCT termasuk kurang (52.9\%), sikap termasuk negatif (55.7\%), pendidikan menengah (52.9\%), sebagian besar tidak bekerja (67.1\%), lebih dari setengah kurang mendapat dukungan suami (57.1\%), dan sebagian besar tidak memanfaatkan layanan VCT (72.9\%). Faktor yang berhubungan dengan pemanfaatan VCT adalah pengetahuan ( $\mathrm{p}$ value 0,000 ), sikap ( $p$ value 0,000 ), pendidikan ( $p$ value 0,000 ) dan dukungan suami ( $p$ value 0.000 ), faktor yang tidak berhubungan adalah pekerjaan ( $\mathrm{p}$ value 0,196$)$. Kesimpulan dari penelitian ini faktor yang berhubungan dengan pemanfaatan VCT adalah pengEtahuan, sikap, pendidikan dan dukungan suami. Oleh karena itu sebaiknya tenaga kesehatan khususnya perawat petugas melakukan pelayanan keperawatan pada ibu hamil khususnya pemanfaatan layanan VCT sebagai upaya dalam deteksi dini terhadap HIV pada ibu hamil.
\end{abstract}

Kata kunci : Faktor-faktor, Pemanfaatan Layanan VCT

\section{Abstract}

Human Immunodeficiency Virus (HIV) is a condition where a person does not have immunity. The disease can be transmitted from pregnant women to the child they are carrying, in an effort to detect early HIV, VCT needs to be done. Karanganyar Community Health Center data in 2017 VCT service coverage for pregnant women in 2017 was less than 26.7\%. This study aims to determine the factors associated with the use of VCT in pregnant women. This type of research is quantitative by using descriptive correlation method and cross sectional approach. The population is 70 pregnant women who were obtained by purposive sampling technique. Data obtained by closed questionnaire and data analyzed using frequency distribution and chi square test. The results showed knowledge about VCT examination included less (52.9\%), attitudes included negative (55.7\%), secondary education (52.9\%), most did not work (67.1\%), more than half received less support from their husbands $(57.1 \%)$, and most did not utilize VCT services (72.9\%). Factors related to the use of VCT are knowledge ( $p$ value 0,000), attitude ( $p$ value 0,000), education ( $p$ value 0,000) and husband's support ( $p$ value 0,000), unrelated factors are work ( $p$ value 0.196). The conclusion from this study factors related to the use of VCT are knowledge, attitudes, education and husband's support. Therefore, it is better for health workers, especially nurses, to provide nursing services to pregnant women, especially the use of VCT services as an effort in early detection of HIV in pregnant women.

Keywords: Factors, Utilization of VCT Services 


\section{PENDAHULUAN}

Human Immunodeficiency Virus (HIV) merupakan suatu keadaan dimana seseorang tidak memiliki kekebalan tubuh. Penyebaran HIV ini berkembang dengan cepat dan mengenai perempuan dan anakanak. Perempuan usia reproduksi yang terinfeksi dengan HIV semakin meningkat jumlahnya di seluruh dunia. Distribusi kasus-kasus HIV di Indonesia mayoritas berusia reproduktif aktif usia 15-49 tahun dan sebanyak 28\% diantaranya adalah perempuan. Selain itu, risiko penularan dari ibu ke bayi berpotensi meningkat karena terdapat 3.200 ibu rumah tangga pengidap HIV di Indonesia. Secara nasional terdapat 1. $200 \mathrm{ibu}$ hamil yang dinyatakan positif mengidap HIV. Sehingga, karena lebih banyak perempuan hamil yang terinfeksi, kemungkinan akan menularkan infeksi pada anaknya.

Dampaknya adalah bayi tumbuh menjadi anak yang mewarisi HIV positif akan lebih sering mengalami penyakit infeksi dan sering mengalami gangguan tumbuh kembang bahkan sampai menyebabkan kematian. Jumlah penderita HIV/AIDS di Kota Tasikmalaya menunjukan grafik peningkatan setiap tahunnya. Data yang dihimpun dari Dinas Kesehatan Kota Tasikmalaya mencatat kasus HIV/AIDS pada tahun 2016 dari 21 kecamatan yang ada di Kota Tasikmalaya menunjukan pengidap HIV/AIDS di Kota Tasikmalaya mencapai 254 kasus.

Upaya yang dilakukan untuk pencegahan HIV melalui pelayanan Voluntary Counselling and testing atau yang dikenal dengan singkatan VCT (WHO, 2015). Konseling dan tes sukarela atau Voluntary Counseling and Testing (VCT) merupakan pintu masuk (entry point) untuk membantu masyarakat mendapatkan akses ke semua pelayanan, baik informasi, edukasi, terapi dan dukungan psikososial (Depkes, 2008). Dengan terbukanya akses, maka kebutuhan akan informasi yang tepat dan akurat akan tercapai, sehingga proses berpikir dan perilaku dapat diarahkan menjadi lebih sehat. Pelayanan VCT dapat digunakan untuk mengubah perilaku berisiko, memberikan informasi yang benar tentang pencegahan dan penularan HIV, seperti penggunaan kondom, tidak berbagi alat suntik, pengetahuan tentang IMS (infeksi menular seksual) dan lain-lain.

Hasil penelitian yang dilakukan Ermarini (2013) terlihat bahwa faktor yang mempengaruhi perilaku seseorang dalam pemanfaatan layanan VCT yaitu keyakinan seseorang dengan pemanfaatan layanan VCT, motivasi atau dukungan dari LSM dan petugas kesehatan serta akses ke layanan VCT. Hasil penelitiannya didapatkan dua variabel yang dominan 
berhubungan berhubungan dengan pemanfaatan layanan VCT yaitu usia dan pengetahuan terkait VCT. Menurut Mugisha (2010) dalam Wati (2013) adapun yang diperlukan untuk mendukung seseorang memanfaatkan layanan VCT meliputi sensitifitas terhadap pengujian, mobilisasi masyarakat, dan peningkatan kualitas dan kuantitas VCT. Dari penelitian Nguyen (2007) dalam Wati (2013) beberapa faktor yang mempengaruhi seseorang memanfaatkan layanan VCT yaitu informasi mengenai keberadaan layanan VCT. Oleh karena itu, hasil penelitian ini menekankan pentingnya peran pembangunan jaringan dengan rumah sakit, lembaga swadya masyarakat, serta masyarakat perkotaan dan pedesaan dalam menyebarluaskan informasi terkait VCT.

\section{METODE PENELITIAN}

Metode dalam penelitian ini adalah deskriptif korelasi dengan metode survey dengan pendekatan cross sectional .Populasi dalam penelitian ini ibu hamil trimester I di wilayah kerja Puskesmas Karanganyar Kota Tasikmalaya periode Juni tahun 2018 yang berjumlah 236 orang. Sampel 70 orang dengan teknik purposive sampling. Hasil uji validitas didapatkan $\mathrm{r}$ hitung lebih besar daripada $r$ tabel $(0,444)$ sehingga pertanyaan tersebut valid, nilai 0,578 - 0,741.Uji reliabilitas didapatkan nilai alpha untuk variabel pengetahuan sebesar 0,975, sikap sebesar 0,922 dan dukungan suami sebesar 0,964 sehingga kuesioner tersebut sangat reliabel. Analisis yang digunakan untuk pengetahuan dan sikap adalah median. Sedangkan untuk variabel dukungan suami yang digunakan dalah mean.

\section{HASIL DAN PEMBAHASAN}

\section{Hasil Penelitian}

Hasil penelitian berdasarkan data yang diperoleh tentang pemanfaatan VCT pada ibu hamil meliputi pengetahuan, sikap, pendidikan, pekerjaan, dan dukungan suami dapat diurai sebagai berikut:

a. Hubungan antara pengetahuan dengan pemanfaatan VCT

Tabel. 1 Hubungan antara pengetahuan dengan pemanfaatan VCT pada ibu hamil di Wilayah Kerja Puskesmas Karanganyar Kota Tasikmalaya.

\begin{tabular}{|c|c|c|c|c|c|c|c|}
\hline \multirow{3}{*}{$\begin{array}{l}\text { Pengeta } \\
\text { huan }\end{array}$} & \multicolumn{4}{|c|}{$\begin{array}{c}\text { Pemanfaatan Layanan } \\
\text { VCT }\end{array}$} & \multirow{2}{*}{\multicolumn{2}{|c|}{ Total }} & \multirow{3}{*}{$\begin{array}{l}\mathrm{P} \\
\text { val } \\
\text { ue }\end{array}$} \\
\hline & \multicolumn{2}{|c|}{ Ya } & \multicolumn{2}{|c|}{ Tidak } & & & \\
\hline & $\mathbf{F}$ & $\%$ & $\mathbf{F}$ & $\%$ & Jml & $(\%)$ & \\
\hline Baik & 17 & 51.5 & 16 & 48.5 & 33 & 100 & 0.0 \\
\hline Kurang & 2 & 5.4 & 35 & 94.6 & 37 & 100 & 00 \\
\hline Jumlah & 19 & 27.1 & 51 & 72.9 & 70 & 100 & \\
\hline
\end{tabular}

Data pada table 1, menunjukkan bahwa ibu yang berpengetahuan baik sebanyak $51.5 \%$ memanfaatkan layanan VCT dan dari ibu hamil yang memiliki pengetahuan kurang sebanyak 94.6\% tidak memanfaatkan layanan VCT. Hasil uji statistik diperoleh nilai $\mathrm{p}$ value 0.000 artinya terdapat hubungan yang signifikan 
antara pengetahuan dengan pemanfaatan layanan VCT.

b. Hubungan antara sikap dengan pemanfaatan VCT

Tabel 2 Hubungan antara sikap dengan pemanfaatan VCT pada ibu hamil di Wilayah Kerja Puskesmas Karanganyar Kota Tasikmalaya.

\begin{tabular}{|c|c|c|c|c|c|c|c|}
\hline \multirow{4}{*}{ Sikap } & \multicolumn{4}{|c|}{ Pemanfaatan Layanan } & \multirow{3}{*}{ Total } & & \multirow{3}{*}{$\begin{array}{l}P \\
v a\end{array}$} \\
\hline & \multicolumn{4}{|c|}{ VCT } & & & \\
\hline & \multicolumn{2}{|c|}{ Ya } & \multicolumn{2}{|c|}{ Tidak } & & & \\
\hline & $\mathbf{F}$ & $\%$ & $\mathbf{F}$ & $\%$ & Jml & $(\%)$ & te \\
\hline Positif & 16 & 51.6 & 15 & 48.4 & 31 & 100 & 0.0 \\
\hline Negatif & 3 & 7.7 & 36 & 92.3 & 39 & 100 & 00 \\
\hline Jumlah & 19 & 27.1 & 51 & 72.9 & 70 & 100 & \\
\hline
\end{tabular}

Data pada tabel 2, menunjukkan bahwa ibu yang bersikap positif sebanyak $51.6 \%$ memanfaatkan layanan VCT dan dari ibu hamil yang memiliki sikap negatif sebanyak $92.3 \%$ tidak memanfaatkan layanan VCT. Hasil uji statistik diperoleh nilai $\mathrm{p}$ value 0.000 artinya terdapat hubungan yang signifikan antara sikap dengan pemanfaatan layanan VCT

c. Hubungan antara pendidikan dengan pemanfaatan VCT

Tabel 3 Hubungan antara pendidikan dengan pemanfaatan VCT pada ibu hamil di Wilayah Kerja Puskesmas Karanganyar Kota Tasikmalaya.

\begin{tabular}{|c|c|c|c|c|c|c|c|}
\hline \multirow{3}{*}{$\begin{array}{l}\text { Pendidi } \\
\text { kan }\end{array}$} & \multicolumn{4}{|c|}{$\begin{array}{c}\text { Pemanfaatan Layanan } \\
\text { VCT }\end{array}$} & \multirow{2}{*}{\multicolumn{2}{|c|}{ Total }} & \multirow{3}{*}{$\begin{array}{l}\mathrm{P} \\
\text { val } \\
\text { ue }\end{array}$} \\
\hline & \multicolumn{2}{|c|}{ Ya } & \multicolumn{2}{|c|}{ Tidak } & & & \\
\hline & $\mathbf{F}$ & $\%$ & $\mathbf{F}$ & $\%$ & $\mathbf{J m l}$ & (\%) & \\
\hline Tinggi & 9 & 60.0 & 6 & 40.0 & 15 & 100 & 0.0 \\
\hline Rendah & 10 & 18.2 & 45 & 81.8 & 55 & 100 & 04 \\
\hline Jumlah & 19 & 27.1 & 51 & 72.9 & 70 & 100 & \\
\hline
\end{tabular}

bahwa ibu yang berpendidikan tinggi sebanyak $60.0 \%$ memanfaatkan layanan
VCT, ibu yang berpendidikan rendah sebanyak $81.8 \%$ tidak memanfaatkan layanan VCT. Hasil uji statistik diperoleh nilai $p$ value 0.004 artinya terdapat hubungan yang signifikan antara pendidikan dengan pemanfaatan layanan VCT.

d. Hubungan antara pekerjaan dengan pemanfaatan VCT

Tabel 4 Hubungan antara pekerjaan dengan pemanfaatan VCT pada ibu hamil di Wilayah Kerja Puskesmas Karanganyar Kota Tasikmalaya.

\begin{tabular}{|c|c|c|c|c|c|c|c|}
\hline \multirow{4}{*}{$\begin{array}{l}\text { Pekerja } \\
\text { an }\end{array}$} & \multicolumn{4}{|c|}{ Pemanfaatan Layanan } & \multirow{3}{*}{ Total } & & \multirow{4}{*}{$\begin{array}{l}\text { P } \\
\text { val } \\
\text { ue }\end{array}$} \\
\hline & \multicolumn{4}{|c|}{ VCT } & & & \\
\hline & \multicolumn{2}{|c|}{ Ya } & \multicolumn{2}{|c|}{ Tidak } & & & \\
\hline & $\mathbf{F}$ & $\%$ & $\mathbf{F}$ & $\%$ & Jml & $(\%)$ & \\
\hline Bekerja & 9 & 39.1 & 14 & 60.9 & 23 & 100 & \\
\hline $\begin{array}{l}\text { Tidak } \\
\text { bekerja }\end{array}$ & 10 & 21.3 & 37 & 78.7 & 47 & 100 & 96 \\
\hline Jumlah & 19 & 27.1 & 51 & 72.9 & 70 & 100 & \\
\hline
\end{tabular}

Data pada tabel 4, menunjukkan bahwa ibu yang bekerja sebanyak 39.1\% memanfaatkan layanan VCT dan dari ibu hamil yang tidak bekerja sebanyak 78.7\% tidak memanfaatkan layanan VCT. Hasil uji statistik diperoleh nilai $\mathrm{p}$ value 0.196 artinya tidak terdapat hubungan yang signifikan antara pekerjaan dengan pemanfaatan layanan VCT. 
e. Hubungan antara dukungan suami dengan pemanfaatan VCT

Tabel 5 Hubungan antara dukungan suami dengan pemanfaatan VCT pada ibu hamil di Wilayah Kerja Puskesmas Karanganyar Kota Tasikmalaya.

\begin{tabular}{|c|c|c|c|c|c|c|c|}
\hline \multirow{3}{*}{$\begin{array}{l}\text { Dukung } \\
\text { an } \\
\text { suami }\end{array}$} & VCT & \multicolumn{3}{|c|}{ Pemanfaatan Layanan } & \multirow[t]{2}{*}{ Total } & & \multirow{3}{*}{$\begin{array}{l}\mathrm{P} \\
\text { val } \\
\text { ue }\end{array}$} \\
\hline & \multicolumn{2}{|c|}{ Ya } & \multicolumn{2}{|c|}{ Tidak } & & & \\
\hline & $\mathbf{F}$ & $\%$ & $\mathbf{F}$ & $\%$ & Jml & $(\%)$ & \\
\hline $\begin{array}{l}\text { Menduk } \\
\text { ung }\end{array}$ & 17 & 56.7 & 13 & 43.3 & 30 & 100 & 0.0 \\
\hline Kurang & 2 & 5.0 & 38 & 95.0 & 40 & 100 & 80 \\
\hline Jumlah & 19 & 27.1 & 51 & 72.9 & 70 & 100 & \\
\hline
\end{tabular}

Data pada tabel 5, menunjukkan bahwa ibu yang mendapat dukungan dari suami sebanyak $56.7 \%$ memanfaatkan layanan VCT dan dari ibu hamil yang kurang mendapat dukungan suami sebanyak $95.0 \%$ tidak memanfaatkan layanan VCT. Hasil uji statistik diperoleh nilai $\mathrm{p}$ value 0.000 artinya terdapat hubungan yang signifikan antara dukungan suami dengan pemanfaatan layanan VCT.

\section{Pembahasan}

a. Hubungan antara pengetahuan dengan pemanfaatan VCT.

Hasil penelitian didapatkan bahwa ibu yang berpengetahuan baik sebanyak $51.5 \%$ memanfaatkan layanan VCT dan dari ibu hamil yang memiliki pengetahuan kurang sebanyak $\quad 94.6 \%$ tidak memanfaatkan layanan VCT. Hasil uji statistik diperoleh nilai $\mathrm{p}$ value 0.000 artinya terdapat hubungan yang signifikan antara pengetahuan dengan pemanfaatan layanan VCT.

Dengan demikian pernyataan tersebut mendukung hasil analisis statistik. Ada hubungan pengetahuan ibu hamil tentang VCT dengan pemeriksaan VCT di Puskesmas Karanganyar. Minat tersebut diinterpretasikan bahwa, semakin baik pengetahuan ibu hamil tentang VCT maka semakin baik tingkat kesadaran untuk melakukan pemeriksaan VCT.

Data lain ditemukan bahwa terdapat responden yang memiliki pengetahuan kurang sebanyak $94.6 \%$ tidak melakukan kunjungan VCT. Menurut analisis penulis rendahnya pengetahuan yang dimiliki oleh responden menjadikan perlaku kesehatan seperti pemanfaatan VCT tidak terbentuk. Artinya responden tidak mengetahui manfaat, tujuan dan lainnya sehingga responden tidak melakukan pemeriskaan VCT. Hal ini mengindikasikan bahwa perilaku dapat terjadi apabila didasari oleh pengetahuan.

Pengetahuan menjadi salah satu faktor predisposisi yang mempengaruhi pemanfaatan pelayanan VCT oleh masyarakat. Pengetahuan tersebut berupa informasi yang diketahui oleh responden selama proses konseling (Syahrir, 2014). Hasil penelitian ini sesuai dengan hasil penelitian yang dilakukan oleh Annisaa (2015) dengan judul "Tingkat Pengetahuan Ibu Hamil tentang HIV/AIDS dengan Perilaku Pemeriksaan Test PITC (Provider 
Initiated Test and Counselling) $\mathrm{di}$ Puskesmas Sleman Yogyakarta" dengan hasil analisa tidak terdapat hubungan antara tingkat pengetahuan ibu hamil tentang HIV/AIDS dengan perilaku pemeriksaan PITC. Hal ini dapat disebabkan karena kurang berkenannya ibu hamil untuk menunggu dengan waktu yang lebih lama dalam melakukan proses pemeriksaan PITC.

Berdasarkan uraian tersebut penulis berpendapat bahwa responden yang memiliki pengetahuan baik cenderung dapat memiliki perilaku yang baik, sebaliknya responden yang kurang mengetahui manfaat dari VCT cenderung untuk tidak memanfaatkan layanan tersebut.

b. Hubungan antara sikap dengan pemanfaatan VCT

Hasil penelitian didapatkan bahwa ibu yang bersikap positif sebanyak 51.6\% memanfaatkan layanan VCT dan dari ibu hamil yang memiliki sikap negatif sebanyak $92.3 \%$ tidak memanfaatkan layanan VCT. Hasil uji statistik diperoleh nilai $\mathrm{p}$ value 0.000 artinya terdapat hubungan yang signifikan antara sikap dengan pemanfaatan layanan VCT.

Menurut hasil penelitian untuk dua pertanyaan status HIV dapat diketahui dengan cara mengunjunginya dan manfaat VCT dapat diketahui dengan cara mengunjunginya. responden cenderung menjawab setuju. Hal ini menunjukkan bahwa responden bersikap positif terhadap layanan VCT. Namun, masih ada responden yang bersikap negatif terhadap layanan VCT, responden cenderung menjawab tidak setuju.

Hasil penelitian ini didapatkan responden yang memiliki sikap negatif lebihi banyak tidak melakukan kunjungan VCT, dengan demikian sikap yang negatif terhadap pemeriksaan tersebut menjadikan perilaku tidak dapat terjadi. Dalam hal ini responden menganggap kurang penting pemanfatan VCT, bahkan responden menganggap bahwa VCT adalah hal yang kurang etis karena menyangkut pada penyakit sosial dimasyarakat sehingga ibu hamil tidak melalukannya.

Hal ini sesuai dengan Widayatun (2009) yang menyatakan bahwa sikap adalah persepsi /pandangan terhdap suatu objek. Sikap positif dapat menjadikan individu menjadi memiliki responden yang baik sehingga perilakupun dapat terjadi. Sebaliknya respon yang negatif menjadikan individu menjauhi terhadap objek yang tidak disukainya.

Artinya sikap negatif ibu hamil terhadap layanan VCT secara tidak langsung dipengaruhi oleh pengetahuan ibu hamil tentang layanan VCT. Menurut Ajzen (1991), faktor latar belakang (background factors), seperti usia jenis kelamin, suku, status sosial ekonomi, suasana hati, sifat kepribadian, dan pengetahuan mempengaruhi sikap dan 
perilaku individu terhadap sesuatu hal. Hal ini sejalan dengan karakteristik responden mayoritas responden berstatus sebagai ibu rumah tangga dengan pengetahuan buruk tentang layanan VCT, secara tidak langsung kedua faktor tersebut mempengaruhi responden untuk bersikap negatif terhadap VCT.

Berdasarkan uraian tersebut penulis berpendapat bahwa responden yang memiliki sikap positif cenderung dapat memiliki perilaku dalam pemeriksaan VCT, sebaliknya responden yang memiliki sikap negatif cenderung menjauhi atau tidak memanfaatkan layanan tersebut.

c. Hubungan antara pendidikan dengan pemanfaatan VCT

Hasil penelitian didapatkan bahwa ibu yang berpendidikan tinggi sebanyak $60.0 \%$ memanfaatkan layanan VCT, ibu yang berpendidikan rendah sebanyak $81.8 \%$ tidak memanfaatkan layanan VCT. Hasil uji statistik diperoleh nilai $\mathrm{p}$ value 0.004 artinya terdapat hubungan yang signifikan antara pendidikan dengan pemanfaatan layanan VCT.

Dalam hal ini pendidikan berkaitan dengan pengetahuan yang dimiliki ibu. Konsep dasar pendidikan adalah suatu proses belajar, jadi semakin tinggi pendidikan ibu maka semakin mudah pula menerima informasi, sehingga banyak pengetahuan yang dimiliki, sebaliknya pendidikan yang kurang akan menghambat perkembangan sikap seseorang terhadap nilainilai baru yang diperkenalkan.

Sebagian besaar responden dengan pendidikan dasar tidak melakukan pemeriksaan VCT, karena pengetahuan yang dimiliki kurang dan proses penerimaan hal-hal baru yang ada di sekitarnya akan berjalan dengan lambat dan mungkin juga sulit. Begitu pula dengan responden dengan tingkat pendidikan menengah, yang walaupun tingkat pendidikan ini dikatakan cukup baik namun kurangnya sosialisasi yang diberikan kepada para ibu mengenai pemeriksaan VCT dan adanya stigma terhadap penderita HIV membuat para ibu dengan tingkat pendidikan sedang tersebut menjadi takut untuk melakukan pemeriksaan VCT.

Pada penelitian lain oleh Ermarini (2013), mendapatkan hasil yang serupa yaitu responden dengan pendidikan tinggi $67,3 \%$ cenderung memanfaatkan pelayanan VCT. Akan tetapi, dari hasil uji statistik tidak terdapat hubungan yang signifikan antara pendidikan dengan niat ibu hamil untuk memanfaatkan layanan VCT di Wilayah Kerja Puskesmas Ciputat tahun 2014. Penelitian ini didukung dengan Ermarini (2013), tingkat pendidikan seseorang tidak berpengaruh terhadap pemanfaatan layanan VCT. Sejalan dengan penelitian Jilia (2013), bahwa tingkat pendidikan seseorang tidak berpengaruh terhadap upaya pencegahan 
tentang HIV/AIDS ada faktor pendukung yang secara tidak langsung mempengaruhi yaitu jenjang pendidikan dan status pekerjaan.

Penulis berpendapat tingkat Pendidikan seseorang relevansinya akan mempengaruhi dalam memahami suatu informasi atau pengetahuan yang diperolehnya. Sebagai asumsi bahwa berpendidikan tinggi belum tentu memiliki pengetahuan yang baik terkait VCT, karena secara tidak langsung pengetahuan dapat didukung oleh faktor lingkungan seperti dorongan dan motivasi dari orang terdekat.

d. Hubungan antara pekerjaan dengan pemanfaatan VCT

Hasil penelitian didapatkan bahwa ibu yang bekerja sebanyak 39.1\% memanfaatkan layanan VCT dan dari ibu hamil yang tidak bekerja sebanyak 78.7\% tidak memanfaatkan layanan VCT. Hasil uji statistik diperoleh nilai $\mathrm{p}$ value 0.196 artinya tidak terdapat hubungan yang signifikan antara pekerjaan dengan pemanfaatan layanan VCT.

Untuk responden yang tidak bekerja dan tidak melakukan pemeriksaan VCT cukup tinggi karena ibu yang tidak bekerja terlalu sibuk mengurusi keperluan rumah tangganya. Bagi perempuan di rumah mempunyai beban kerja lebih besar dari pada laki-laki, pekerjaan domestik/rumah tangga dilakukan oleh perempuan (Widyastuti dkk, 2009).
Terlebih pada ibu yang tidak bekerja ini tidak memiliki pergaulan lain diluar rumah yang dapat menambah pengetahuan atau informasi baru tentang kesehatan. Beban pekerjaan rumah tangga yang besar dan kurangnya pergaulan diluar rumah yang dapat membuka wawasan tentang kesehatan membuat responden yang tidak bekerja kurang tertarik untuk melakukan pemeriksaan VCT.

e. Hubungan antara dukungan suami dengan pemanfaatan VCT

Hasil penelitian didapatkan bahwa ibu yang mendapat dukungan dari suami sebanyak $56.7 \%$ memanfaatkan layanan VCT dan dari ibu hamil yang kurang mendapat dukungan suami sebanyak 95.0\% tidak memanfaatkan layanan VCT. Hasil uji statistik diperoleh nilai $\mathrm{p}$ value 0.000 artinya terdapat hubungan yang signifikan antara dukungan suami dengan pemanfaatan layanan VCT.

Dukungan suami adalah respon suami terhadap kehamilan istri yang dapat menyebabkan adanya ketenangan batin dan perasaan senang dalam diri istri. Suami adalah orang pertama dan utama dalam memberi dorongan kepada istri sebelum pihak lain turut memberi dorongan, dukungan, dan perhatian seorang suami terhadap istri yang sedang hamil yang akan membawa dampak positif bagi ibu dan bayi ( Franchicandra, 2010).

Penelitian ini sejalan dengan penelitian yang dilakukan oleh Dan 
penelitian oleh Titi Legiati, dkk (2012) yang berjudul Prilaku Ibu Hamil Untuk Tes HIV di Kelurahan Bandarharjo dan Tanjung Mas Kota Semarang didapatkan nilai $p$ value $=0,000$ yaitu ada hubungan yang signifikan antara dukungan suami dengan pemeriksaan VCT pada ibu hamil.

Hasil penelitian didapatkan responden yang kurang mendapat dukungan dari suami sebagian besar tidak memanfaatkan layanan VCT, hal ini disebabkan karena suami merupakan pengambil keputusan dalam keluarga. Walaupun resoponden telah terpapar informasi dari tenaga kesehatan mengenai VCT tersebut, namun pada kenyataan dilapangan responden harus meminta izin kepada suami. Sehingga dalam hal ini perilaku memanfaatkan layanan VCT atau tidaknya tergantung pada keputusan suami.

Menurut asumsi peneliti kurangnya dukungan suami terhadap pelaksanaan pemeriksaan VCT disebabkan oleh tingkat pekerjaan suami yang menyebabkan kurangnya perhatian dan waktu untuk memberikan dukungan atau motivasi kepada ibu hamil untuk melakukan pemeriksaan VCT selama kehamilan dan mengantar ibu hamil memeriksakan kehamilan ke fasilitas kesehatan, ibu hamil lebih banyak di temani oleh keluarga ataupun teman. Suami tidak memiliki cukup pengetahuan mengenai pemeriksaan VCT dan ditemukan banyak suami yang belum melakukan pemeriksaan VCT

\section{KESIMPULAN DAN SARAN}

\section{Kesimpulan}

Berdasarkan hasil penelitian mengenai faktor-faktor yang berhubungan dengan dengan pemanfaatan VCT pada ibu hamil dapat disimpulkan bahwa

1. Terdapat hubungan antara pengetahuan dengan pemanfaatan VCT pada ibu hamil di Wilayah Kerja Puskesmas Karanganyar Kota Tasikmalaya dengan $\mathrm{p}$ value 0,000 .

2. Terdapat hubungan antara sikap dengan pemanfaatan VCT pada ibu hamil di Wilayah Kerja Puskesmas Karanganyar Kota Tasikmalaya p value 0,000 .

3. Terdapat hubungan antara pendidikan dengan pemanfaatan VCT pada ibu hamil di Wilayah Kerja Puskesmas Karanganyar Kota Tasikmalaya dengan p value 0,000 .

4. Tidak terdapat hubungan antara pekerjaan dengan pemanfaatan VCT pada ibu hamil di Wilayah Kerja Puskesmas Karanganyar Kota Tasikmalaya dengan $p$ value 0,196 .

5. Terdapat hubungan antara dukungan suami dengan pemanfaatan VCT pada ibu hamil di Wilayah Kerja Puskesmas Karanganyar Kota Tasikmalaya dengan dengan $p$ value 0,000 .

\section{Saran}

1. Bagi perawat

Sebaiknya tenaga kesehatan khususnya perawat petugas melakukan pelayanan keperawatan pada ibu hamil 
khususnya pemanfaatan layanan VCT sebagai upaya dalam deteksi dini terhadap HIV pada ibu hamil di wilayah kerja Puskesmas dengan meningkatkan pengetahuan, motivasi, memberikan pelatihan keperawatan.

2. Bagi Puskesmas Karanganyar Kota Tasikmalaya

Perlu adanya perbaikan dalam meningkatkan pelayanan kepada ibu hamil khususnya dalam pelayanan VCT serta meningkatkan Pelaksanaan Kegiatan Pembentukan WPA (Warga Peduli AIDS).

3. Bagi FIKes Universitas Muhammadiyah

Sebaiknya hasil penelitian ini dapat menjadi sumber referensi bagi pihak pendidikan dalam rangka kerja sama dengan isntansi kesehatan dalam meningkatkan layanan VCT pada ibu hamil

\section{Peneliti selanjutnya}

Perlu dilakukan penelitian lebih lanjut khususnya mengenai perilaku dalam pencegahan HIV/AIDS pada kehamilan dengan menggunakan metode dan variabel yang lebih luas

1, 2, 3 Fakultas Ilmu Kesehatan,Program

Studi Keperawatan,Universitas

Muhammadiyah Tasikmalaya

E-mail:dudiahmadm@gmail.com

DAFTAR PUSTAKA

Arikunto, (2010). Prosedur Penelitian, Suatu Pendekatan Praktek;Edisi Revisi PT. Asdi Mahasatya

Azwar, (2011). Pengantar Ilmu administrasi Kesehatan. Binarupa Aksara. Tangerang
Depkes, (2008). Pedoman Pelayanan Konseling Dan Testing HIV/AIDS Secara Sukarela (Voluntary Counselling And Testing). Dirjen P2PL : Jakarta

Ermarini (2013). Faktor -Faktor Yang Berhubungan Dengan Pemanfaatan Layanan VCT Pada Populasi Beresiko Tinggi Hiv/Aids Di Provinsi Banten Tahun 2013. Depok: Tesis. Magister Fakultas Kesehatan Masyarakat. Universitas Indonesia.

Februhartanty, (2009). Implementasi Gerakan Keluarga Peduli Kesehatan. http://info. balitacerdas. com/mod. php? Diperoleh Diakses bulan Janauri 2018

Indah,Galuh Pramita (2015). Hubungan Peran Bidan Dengan Kepatuhan Pemeriksaan VCT (VoluntaryCounseling And Testing) pada Ibu Hamil di Wilayah Kerja Puskesmas Gitik Kabupaten Banyuwangi

Kemekes RI 2011. Pedoman Nasional Penularan HIV dari Ibu ke Anak (PPIA), Katalog Dalam Terbitan Kementrian Kesehatan RI, Jakarta

Kemenkes, (2013). Rencana Aksi Nasional Pengendalian HIV DAN AIDS Sektor Kesehatan 2014-2019. Direktorat Jenderal Pengendalian Penyakit dan Penyehatan Lingkungan : Jakarta.

Kemenkes. RI, (2012) Survei Demografi Dan Kesehatan Indonesia Tahun 2012. Badan Kependudukan dan Keluarga Berencana Nasional : Jakarta

Laporan Puskesmas Karanganyar. Laporan Tahunan Puskesmas Karanganyar Tahun 2017/ Puskesmas Karanganyar. Tidak dipublikasikan Mugisha (2010) dalam Wati (2013) . Analisis Kebijakan VCT Dalam Upaya Utilisasi Layanan VCT Di Rumah Tahanan Kelas II A Jakarta Timur Tahun 2013. Depok: Tesis. Fakultas Kesehatan Masyarakat. Universitas Indonesia 
Notoamordjo (2010). Metodologi Penelitian. Teori dan Aplikasi. Rhineka Cipta. Jakarta

Notoatmodjo (2010) Ilmu perilaku danpendidikan kesehatan. Rhineka Cipta. Jakarta

Nurhayati (2016). Faktor-faktor yang berhubungan dengan keikutsertaan ibu hamil dalam pemeriksaan VCT di Puskesmas. Volume 1. No. 3 Tahun 2016. Jurnal Human Care. STIKes Fort De Kock, Bukittinggi

Pedoman Pelayanan VCT, (2008) Klinik VCT Layanan Mandiri. Clinical Service Unit. FHI. Indonesia

Pramudjito, (2008). Voluntary Counseling and Testing (VCT) Untuk HIV/AIDS

Rohmah, 2010. Pendidikan Prenatal; Upaya Promosi Kesehatan Bagi Ibu Hamil. Depok. Gramata

Saam (2012). Psikologi Keperawatan. Raja Grafindo Persada. Jakarta

Sugiyono, (2011). Metode Penelitian Kuantitatif dan Kualitatif. Alfabeta. Bandung
UNAIDS/WHO (2013) UNAIDS Report On The Global AIDS Epidemic 2013. Global Report. UNAIDS

Wawan dan Dewi, 2010. Pengukuran Pengetahuan, Sikap dan Perilaku Manusia. Nuha Medika. Jogjakarta

WHO, (2015). Prevention of Mother to child Transmission of HIV To Reach The UNGASS And Millenium Development Goals. PMTCT Strategic Vission 20102015.

Zainurie, (2011). Cara Seseorang Memperoleh Pengetahuan Dan Implikasinya Pada Pembelajaran Matematika. http://zainurie. wordpress. com diakses Tahun 2018. 